International Journal of Life Sciences
Available online at http://sciencescholar.us/journal/index.php/ijls
Vol. 3 No. 1, April 2019, pages: $48 \sim 55$
e-ISSN: 2550-6986, p-ISSN: $2550-6994$
https://doi.org/10.29332/ijls.v3n1.258

\title{
Discovering Ditch Buried Volcanic Materials: Geoelectric Method Assistance to Minimize Hazard Loss
}

\author{
(2) CrossMark
}

I Nengah Simpen a, Ni Made Widya Pratiwi ${ }^{b}$

Article history: Received 27 July 2018, Accepted: 31 December 2018, Published: 24 March 2019

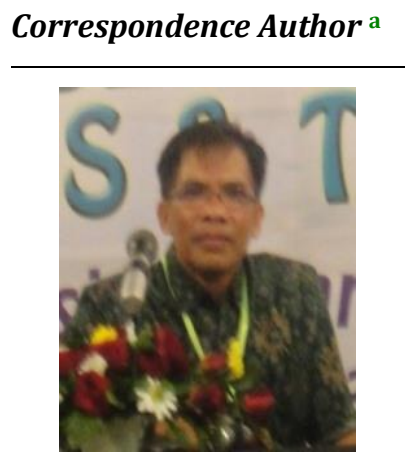

Keywords

agricultural land;

ditch buried;

eruption;

geoelectric method;

volcanic material;

\begin{abstract}
The current study is aimed at discovering ditch buried volcanic materials: geoelectric method assistance to minimize hazard loss. The research has been conducted at Bugbug Karangasem Bali. This covered by volcanic material from the eruption of Mount Agung in 1963 and before. Of course, there is a ditch as a land boundary. Based on the measurement results of the geoelectric method, it was found that there was a low resistivity area of $26.5 \Omega \mathrm{m}$ at a depth of about 7 $\mathrm{m}$ area $\mathrm{A}$ and $23.5 \mathrm{~m}$ (area B). Based on the excavation at several points, the thickness of the volcanic material layer in the study area is around $7 \mathrm{~m}$. The landowners have claimed that their land is restricted by a ditch, which when Mount Agung erupted in 1963, had been covered with volcanic material; a ditch was made, but between the trenches made with the low-resistivity area A sideways again $11 \mathrm{~m}$. The low resistivity is thought to be a buried ditch. As it is connected to the two cases above, namely the case of the results of geoelectric measurements and cases of landowners' suitability. The ditch that has been buried by volcanic material can be detected by geoelectric methods assistance.
\end{abstract}

e-ISSN: 2550-6986, p-ISSN: 2550-6994 ๑ Copyright 2019. The Author. SS Journals Published by Universidad Técnica de Manabí. This is an open-access article under the CC BY-SA 4.0 license (https://creativecommons.org/licenses/by-sa/4.0/) All rights reserved.

\section{Contents}

Abstract

1. Introduction

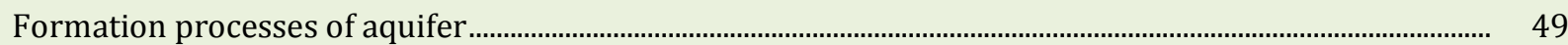

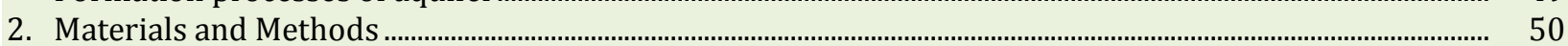

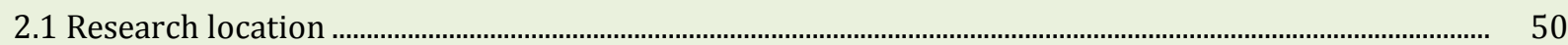

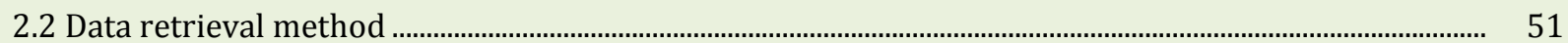

2.3 Data analysis method........................................................................................................................................... 51

a Physics Department, Mathematical and Science Faculty, Udayana University, Denpasar, Indonesia

b Civil Engineering Department, Engineering Faculty, Warmadewa University, Denpasar, Indonesia 


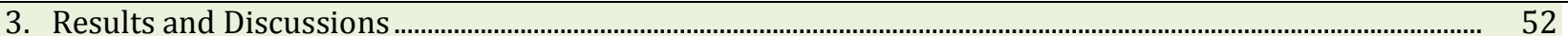

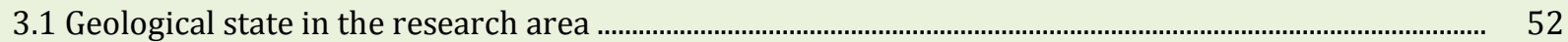

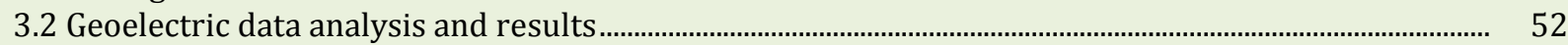

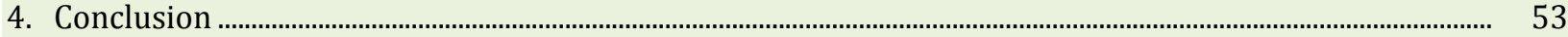

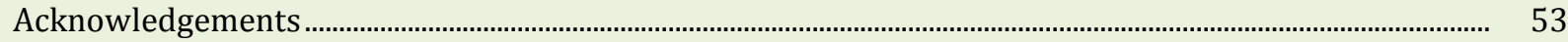

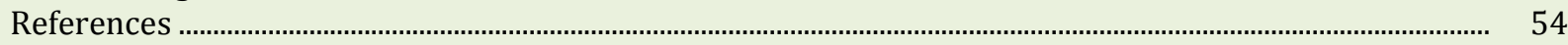

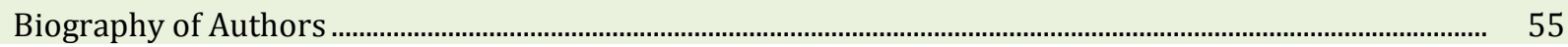

\section{Introduction}

Indonesia is located on the ring of fire. This condition causes prone to eruption. The volcanic track starts from Sumatra - Java - Bali - Nusa Tenggara - Sulawesi - Banda - Maluku - Papua (Suharmantoa et al., 2015). The hazard of volcanic eruptions consists of two hazards, namely primary hazards and secondary hazards. Primary hazard is the hazard that directly affects the population when the eruption takes place. for example, hot clouds, hot air as a side effect of hot clouds, and the throwing of block-sized material (bombs) to gravel. While secondary hazards occur indirectly and generally take place after an eruption occurs, such as cold lava which can cause land damage and settlements (Rahayu et al., 2014). Damage also occurs in the social economic activities of the community in the disaster area. The presence of volcanic eruptions is very troubling to the surrounding community. Basically, erupting mountains is one of the disasters that have complex consequences. Soil surface on volcanic eruption land is covered by lava, pyroclastic flow and also tephra (volcanic dust) and lava. Lava deposits vary greatly in the thickness of their cover to the surface of the land, starting from a few centimeters to tens of meters. Although there are many negative impacts, there are also positive effects, namely the presence of building materials in the form of stones and sand. Volcanic material carried by the water flow from upstream to downstream, covering all the places that were passed. One of the effects is the border of the rice fields is lost. People can no longer remember where the land boundary is. After the volcanic material flow subsided, people searched the boundaries of their fields. There are mutual claims to border issues. Due to there is no definite guideline, there will be a lot of damage to the rice field as a result of uncertain borders. For this reason, a solution is needed to minimize disaster losses both in terms of the economy and social aspects.

Rice fields are usually ditch. Geomorphologically, if the ditch is closed, volcanic material can change into an aquifer (Simpen, 2015). Geophysically, aquifers have low resistivity characteristics. This situation is easily detected by the geoelectric method. The geoelectric method is one of the geophysics that studies the nature of electricity in the earth by injecting an electric current (I) into the earth and measuring the potential difference (V) generated. The electric current injected is in the form of a direct current with a low frequency (Hendrajaya, 1990).

The research about the search for ditch buried by volcanic material with the help of geoelectric methods to minimize the loss of volcanic disasters. The study took place in Bugbug Karangasem Bali. In the study area, there were some areas covered by volcanic material from the eruption of Mount Agung in 1963 and earlier (Hadiwidjojo, 1971), so that the fields were covered by volcanic material. As a result, the boundaries of rice fields were not found with certainty. With the help of the geoelectric method, it is expected to find the boundaries of the fields that are sought.

\section{Formation processes of aquifer}

The formation of aquifers as a result of geomorphological processes. The forces that influence the geomorphological process are exogenous forces, endogenous forces, and forces originating from extraterrestrial (Tjia, 1987). Exogenous strength, forces that come from outside the body of the earth, the forces that can be caused by water, wind, glaciers and living things (humans and animals). As a result of exogenous forces weathering, avalanches, erosion, reshaping and formation on the face of the earth occur. Endogenous forces, forces originating from within the earth, forces that can be caused by volcanoes, geodynamic and earthquake forces. As a result of the endogenous force is the occurrence of magma, lava transport, removal, decrease, folding, cracking and enlargement of the soil layer. Strength originating from

Simpen, I. N., \& Pratiwi, N. M. W. (2019). Discovering ditch buried volcanic materials: geoelectric method assistance to minimize hazard loss. International Journal of Life Sciences, 3(1), 48-55. https://doi.org/10.29332/ijls.v3n1.258 
outside the earth, the presence of meteors and the dust of the cosmos that fell to earth. This is very small and rarely happens.

The results of weathering, avalanches, erosion, and changes to water as an agent will be deposited over valleys, lower areas or following the river flow. Thus it runs continuously during the process and agent results. This event runs slowly. If there were no other powers, then the surface of this earth would be even.

The effect of volcanoes has enormous power in changing the morphology of the earth's surface. Volcanoes at the time of eruption emit volcanic materials that can cover valleys, lower areas or follow the river flow for tens of kilometers in thickness from a few centimeters to tens of meters depending on the area. Likewise with volcanic ash that can reach a wider area. This event repeats continuously as long as the volcano erupts. As a result, the eruption material looks layered according to the type of material deposited. The hardness of the sediment material is very dependent on the temperature and content of the deposited material (Tjia, 1987). The deposited material is non-uniform material from large to sand and clay. Eruption materials are hard and cannot be penetrated by water. This property results in the material being the cover layer of the aquifer. While materials that are not hard and can still be penetrated by water become aquifers.

Based on the location of deposition of geomorphological materials that form aquifers, can be divided into three types (Simpen, 2015), namely:

a) Material that settles along the river channel or ditch, the hard part will be the cover layer or the protective layer, while the layer that cannot be penetrated by water will become an aquifer. In this case, the aquifer will become a vein shape like rivers or buried ditches.

b) Material that settles in a flat structured area, the hard part becomes a cover layer, while the soft part that can be penetrated by water will become an aquifer. The presence of a hard layer and soft layers alternating will form a flat aquifer.

c) The material that settles in the valley, the hard bottom layer is then filled with the soft part and is covered by the hard part and finally covered by the soft part. The arrangement of materials like this will form aquifers in the form of basins.

\section{Materials and Methods}

\subsection{Research location}

The research was conducted in the southern part of Bugbug Karangasem Village, Bali. Based on the Geological Map of Bali, the geology of this area was covered by volcanic material from the eruption of Mount Agung in 1963 and earlier (Hadiwidjojo, 1971), see Figure 1.

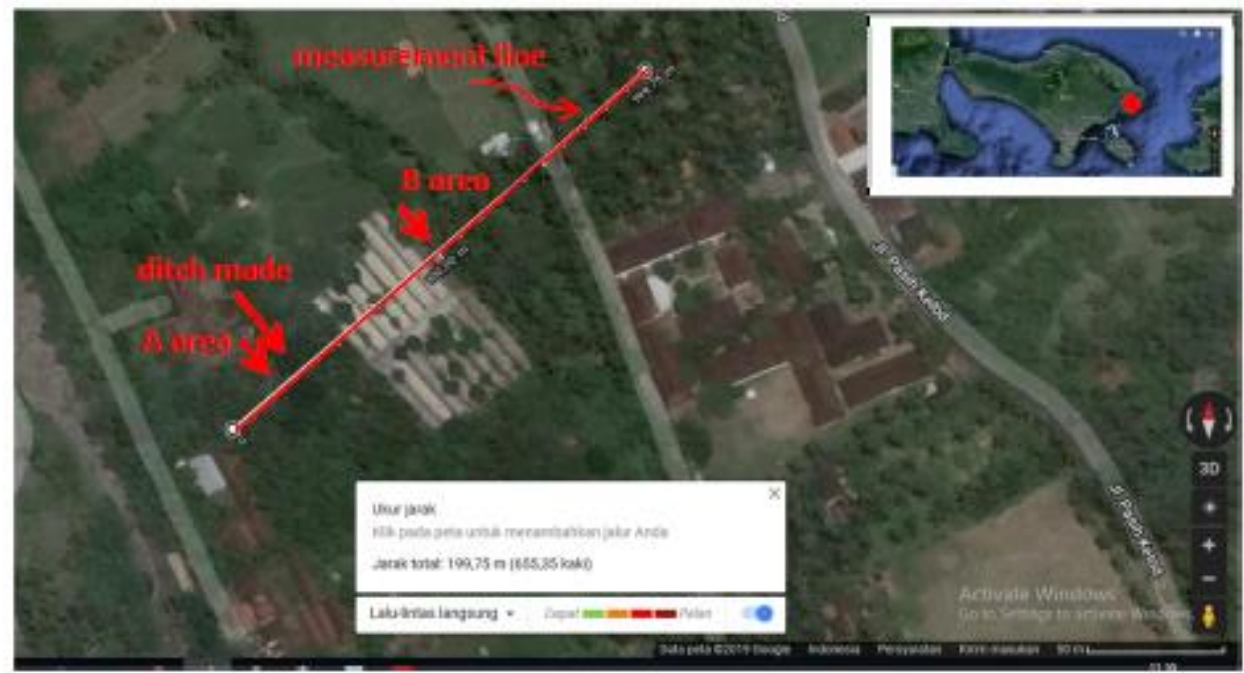

Source: Google map

Figure 1. Research location 


\subsection{Data retrieval method}

Data retrieval is done by the geoelectric method. The geoelectric method uses the electrical properties of rocks as a parameter. This method is an active method, namely by injecting an electric current into the earth and then measuring the potential difference caused. The geoelectric method is one of the geophysics that studies the nature of electricity in the earth by injecting electric current (I) into the earth and measuring the potential difference $(\mathrm{V})$ generated. Electric current is injected in the form of direct electric current low frequency. Geoelectric method measurement scheme can be seen in the following figure (Telford, et al., 1990).

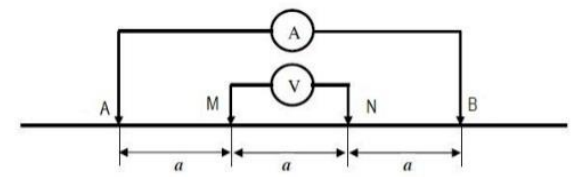

Figure 2. Geoelectric Method Measurement Scheme

The measurement steps are as follows:

a) Make a measurement line.

b) Electrode installation

c) Connect resistivity to electrodes.

d) Take measurements.

Data measurement used SkillPro resistivity tool by the Werner configuration, with a distance between $4.25 \mathrm{~m}$ electrodes. The electrodes used 48 pieces so that the track length became $199.75 \mathrm{~m}$. The placement of the electrode and its magnification is as shown in Figure 3 (Looke, 2000).

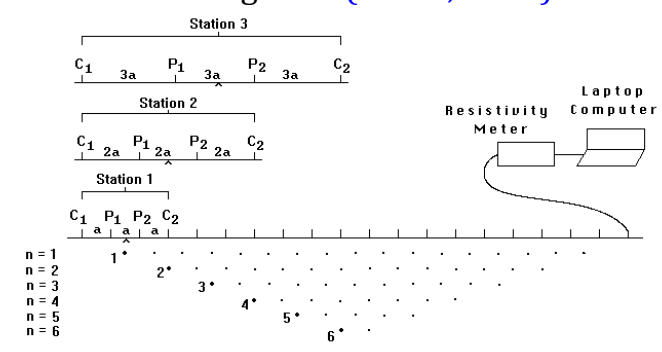

Figure 3. Data Measurement by Wenner Configuration

The relationship between measured current strength (I) with the potential difference generated (V) produces rock resistivity ( $\rho$ ) can be written Legowo et al., (2018); Afandi et al., (2018); Susilo et al., (2018):

$$
\rho=\mathrm{K} \frac{V}{I}
$$

$K=(2 \pi a)$ is Werner constant; a is electrode spacing; I is the current strength injected and V the potential difference and $\rho$ is resistivity. Resistivity results from the calculation in the above is false resistivity. In oreder to get real resistivity, the data $\rho$ must be analyzed by the Res2dinv program. The result calculation is rock resistivity quantities by position and depth. This resistivity is contoured, resulting in a cross-section resistivity contour.

\subsection{Data analysis method}

The measurement results in the form of current magnitude and potential difference and the relationship between the two quantities that produce apparent resistivity need to be analyzed using the Res2dinv program. The analysis output is in the form of contour cross-section resistivity, this contour is interpreted.

Simpen, I. N., \& Pratiwi, N. M. W. (2019). Discovering ditch buried volcanic materials: geoelectric method assistance to minimize hazard loss. International Journal of Life Sciences, 3(1), 48-55. https://doi.org/10.29332/ijls.v3n1.258 


\section{Results and Discussions}

\subsection{Geological state in the research area}

The research location is located in Bugbug Village, Karangasem District, Karangasem Regency, Bali Province, altitude about $23 \mathrm{~m}$ above mean sea level, coordinates around 8,498507 S, 115,594350 E. Rock formations around research area is covered by the volcanic material eruption of Mount Agung. This condition as well as Geology Map of Bali area, so that in this area there is an estimated buried ditch by volcanic material. Based on information from local residents, it is true that in the area there is a ditch as a rice field barrier. The location of the ditch uses approximately (uncertain), so that for the agreement to be ditch (Figure 1).

\subsection{Geoelectric data analysis and results}

Measurement line is made in the research area (see Figure 1). This line is the lines where geoelectric measurements are done. Photos of measurement activities can be seen in the following figure.

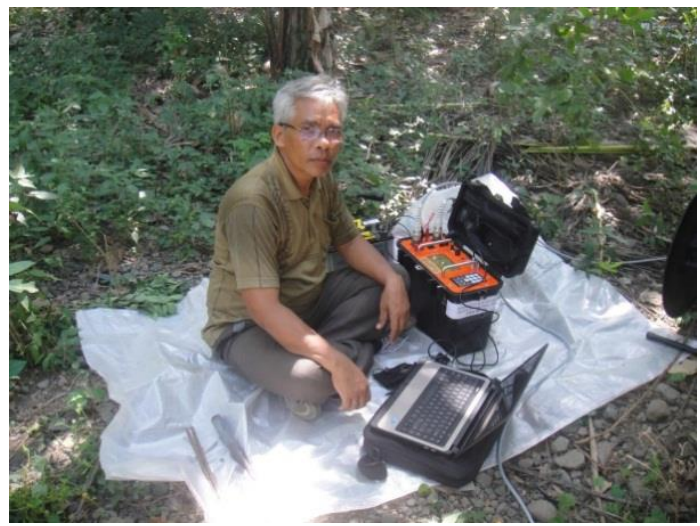

Figure 4. Geoelectric data measurement

The geoelectric equipment used is SkillPro by Wenner configuration. Geoelectric data is initially in the form of injected current strength (I) quantities and potential difference magnitude $(\Delta V)$ due to current injection. But in the SkillPro geoelectric toolset can be directly obtained the amount of apparent resistivity at the measurement points. The apparent resistivity value is analyzed by the Res2dinv program to obtain the real resistivity value of each measurement point. The real resistivity contours of cross-section can be seen in Figure 5.

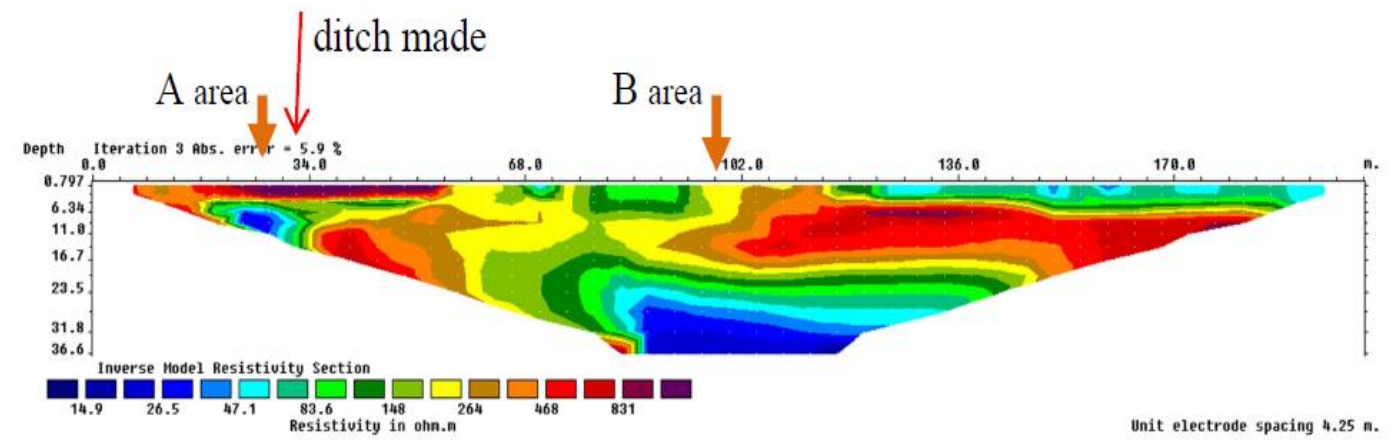

Figure 5. Cross-section resistivity contour

Based on the results of the measurement of the geoelectric method as shown in Figure 5, there appears to be a low resistivity area of $26.5 \Omega \mathrm{m}$ at a depth of about $7 \mathrm{~m}$ (area A) and $22.5 \mathrm{~m}$ (area B). The excavation at point A found a row of rocks and the presence of water at a depth of $6.75 \mathrm{~m}$. This row of stones is thought to be the wall of a ditch buried by the eruption of Mount Agung in 1963. In area B, after drilling, it was found that 
there were aquifers at a depth of $22.5 \mathrm{~m}$. Thus, the low resistivity in area B is thought to be a ditch buried by the eruption material of Mount Agung before 1963.

When linked to the two cases above, namely the case of geoelectric measurements and the case of making a ditch, it turned out that the ditch that had been made deviated $11 \mathrm{~m}$ from the ditch obtained based on geoelectric data. This situation can be understood because the location of the ditch is still used so that there are still deviations. The presence of water in the excavation in area $A$ and the presence of water in drilling in area B shows that buried trenches can become aquifers as described by Simpen (2015) and can be detected by the geoelectric method.

\section{Conclusion}

The ditch buried in volcanic material can be searched by geoelectric methods. The discovery of the ditch as the border of the rice fields has provided a definite point for further measurements. As a result, the loss of the rice fields can be minimized.

\section{Acknowledgments}

This paper has been presented at the National Conference Consep and Implementation \#3 by Warmadewa University, on November 7, 2018, in Denpasar Bali, and has been improved according to congressional suggestions. We would like to thank the Committee of the National Conference Consep and Implementation \#3 for accepting this paper and also thanks the all National Conference Consep and Implementation \#3 participants for their suggestions.

Simpen, I. N., \& Pratiwi, N. M. W. (2019). Discovering ditch buried volcanic materials: geoelectric method assistance to minimize hazard loss. International Journal of Life Sciences, 3(1), 48-55. https://doi.org/10.29332/ijls.v3n1.258 


\section{References}

Afandi, A., Catrawedarma, I. G. N. B., Maryanto, S., Nadhir, A., Zaman, M. B., \& Pambudi, N. A. (2018). Identification of reservoir thickness of ijen (geothermal prospect area, indonesia) using resistivity method with schlumberger configuration. International journal of geomate, 15(52), 68-75.

Hendrajaya, L., \& AVIF, I. (1990). Type Resist Geoelectric, Earth Physics Laboratory. Department of Physics, Faculty of Mathematics and Natural Sciences, Bandung Institute of Technology.

Legowo, B., Putra, A. G., \& Kurniawan, M. F. R. (2018, March). Identification groundwater aquifer by using geoelectrical method: case study Pondok Pesantren Darussallam, Kradenan, Grobogan. In Journal of Physics: Conference Series (Vol. 983, No. 1, p. 012030). IOP Publishing. https://iopscience.iop.org/article/10.1088/1742-6596/983/1/012030/pdf

Loke, M. H. (1999). Electrical imaging surveys for environmental and engineering studies. A practical guide to, 2. http://moho.ess.ucla.edu/ pdavis/ESS135_2013/LITERATURE/\%20LokeDCREsistivity.pdf

Purbo-Hadiwidjojo, M. M. (1971). Peta Geologi 1: 250 000: Lembar, Bali. Volcanological Observation Post.

Rahayu, R., Ariyanto, DP, Komariah, K., Hartati, S., Syamsiyah, J., \& Dewi, WS (2014). Impact of Mount Merapi Eruption on Land and Recovery Efforts. Caraka Tani: Journal of Sustainable Agriculture , 29 (1), 61-72. http://dx.doi.org/10.20961/carakatani.v29i1.13320

Simpen, IN (2015). Solution to the Problems of Drilled Wells Versus Wells by Geoelectric Method and Well Pumping Test (A Case Study in Bugbug Karangasem Bali). Preliminary 2015 National Seminar on Physics and Learning, Malang State University .

Suharmanto, P., Fitria, A. N., \& Ghaliyah, S. (2015). Indonesian geothermal energy potential as source of alternative energy power plant. KnE Energy, 1(1), 119-124. http://dx.doi.org/10.18502/ken.v1i1.325

Susilo, A., Sunaryo, \& Fitriah, F. (2018). Groundwater investigation using resistivity method and drilling for drought mitigation in tulungagung, indonesia. International journal of geomate, 15(47), 124-131.

Telford, W. M., Telford, W. M., Geldart, L. P., Sheriff, R. E., \& Sheriff, R. E. (1990). Applied geophysics (Vol. 1). Cambridge university press. https://books.google.co.id/books?hl=en\&lr=\&id=oRP5fZYjhXMC\&oi

Tjia, HD (1987). Geomorphology . Language and Library Council. 


\section{Biography of Authors}

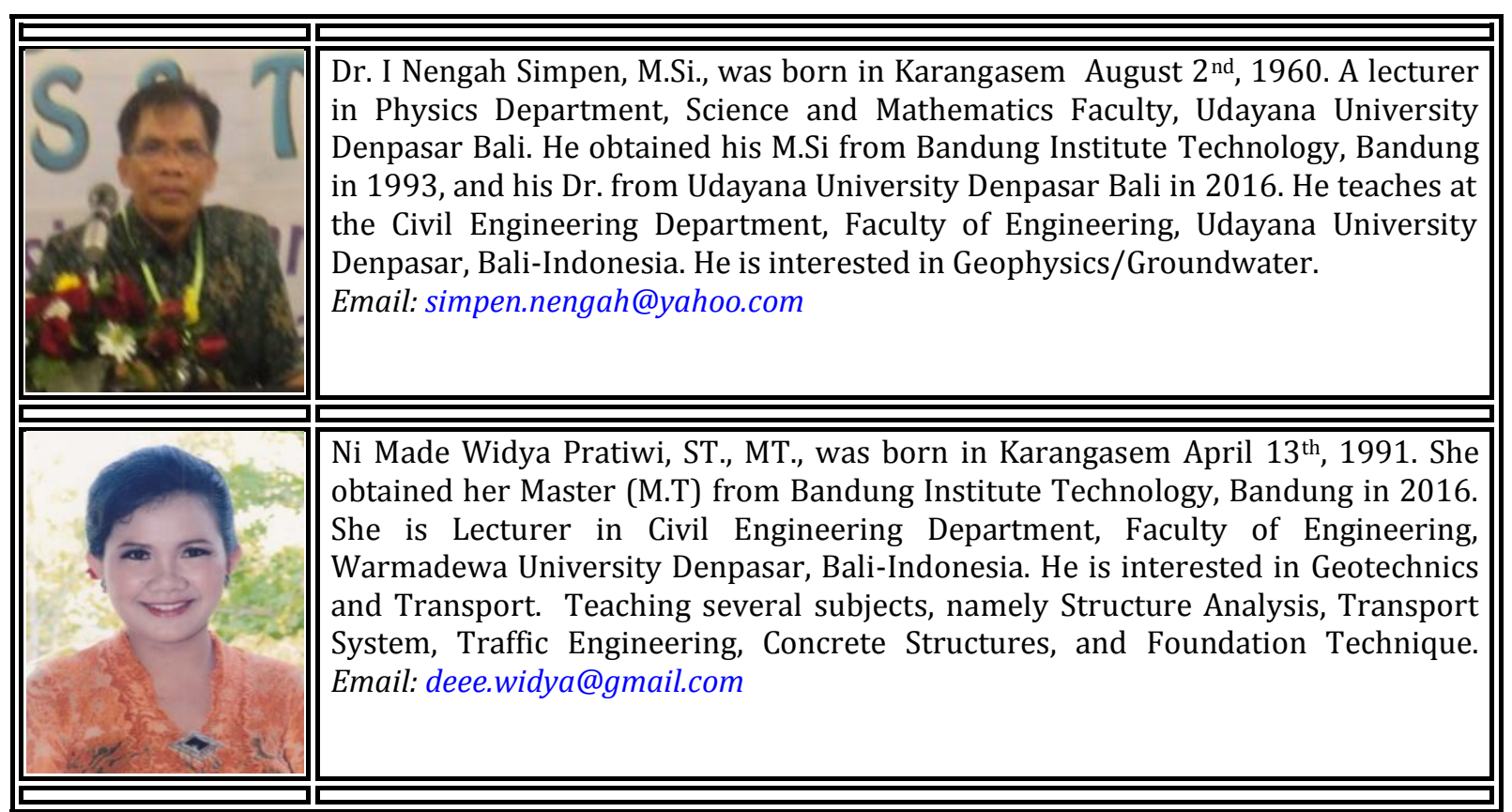

Simpen, I. N., \& Pratiwi, N. M. W. (2019). Discovering ditch buried volcanic materials: geoelectric method assistance to minimize hazard loss. International Journal of Life Sciences, 3(1), 48-55. https://doi.org/10.29332/ijls.v3n1.258 